\title{
Progesterone Enhances an Estradiol-Induced Increase in Fos Immunoreactivity in Localized Regions of Female Rat Forebrain
}

\author{
Anthony P. Auger and Jeffrey D. Blaustein \\ Neuroscience and Behavior Program and Psychology Department, University of Massachusetts, Amherst, \\ Massachusetts 01003
}

In female rats, the onset of reproductive behavior depends on the sequential presence of estradiol followed by progesterone. Although treatment with high doses of estradiol has been shown to increase immunostaining for the Fos protein, an immediate early gene product that is expressed upon cellular activation, another report conflicts with this finding. However, the previous reports agree that subsequent treatment with progesterone has no apparent effect on Fos expression. In order to resolve this discrepancy and investigate possible effects of progesterone, we used Fos immunocytochemistry combined with computer-aided image analysis. In experiment one, we found that treatment with $5 \mu \mathrm{g}$ of estradiol increased Fos immunoreactivity (Fos-IR) within a section of the medial preoptic area and the dorsal medial hypothalamus. Subsequent treatment with $500 \mu \mathrm{g}$ of progesterone $1 \mathrm{hr}$ before perfusion increased the intensity of the immunostaining within the medial preoptic area and the dorsal medial hypothalamus, although it had no significant effect on Fos-IR cell number. In experiment 2, a lower concentration of Fos antiserum was used in order to diminish the immunostaining sensitivity to a level in which no increase of Fos-IR cell number was observed after treatment with estradiol. Under these immunocytochemical conditions, subsequent treatment with progesterone increased the number of Fos-IR cells in the medial preoptic area, the dorsal medial hypothalamus and the steroid receptor-rich area lateral to the ventromedial hypothalamus. Thus, treatment with behaviorally effective doses of both estradiol and progesterone induces Fos expression in localized regions of female rat brain.

[Key words: estradiol, progesterone, steroid hormones, proto-oncogenes, c-fos, hypothalamus, immunocytochemistry, image analysis]

During the estrous cycle, reproductive behavior in female rats depends on an increase in estradiol levels followed by a surge of progesterone a few hours before the onset of sexual receptivity (Boling and Blandau, 1939; Smith et al., 1975). Sexual re-

\footnotetext{
Received May 16, 1994; revised Sept. 19, 1994; accepted Sept. 23, 1994.

This research was supported by Grants NS 19327 from the National Institutes of Health and RSDA MH 00885 from the National Institute of Mental Health. We gratefully acknowledge Marc Tetel, John Meredith, and Joanne Turcotte for technical assistance. We also thank Brad Powers and George Wade for comments on the manuscript.

Correspondence should be addressed to Jeffrey D. Blaustein, Psychology Department, Tobin Hall-Box 37710, University of Massachusetts, Amherst, MA 01003-7710.

Copyright (C) 1995 Society for Neuroscience $\quad 0270-6474 / 95 / 152272-08 \$ 05.00 / 0$
}

ceptivity is abolished by ovaricetomy and reinstated by injection of steroid hormones (Boling and Blandau, 1939). The sequential treatment with estradiol and progesterone is important for the induction of sexual receptivity (Boling and Blandau, 1939; Powers, 1970). In ovariectomized rats, estradiol primes the animal for a subsequent injection of progesterone about $48 \mathrm{hr}$ later and progesterone-facilitated receptivity occurs within a few hours (Boling and Blandau, 1939).

One mechanism by which steroid hormones act in some tissues is by binding to intracellular receptors causing a conformational change that allows the receptors to bind to DNA (Jensen et al., 1968; Walters, 1985). Once the steroid-receptor complex binds to DNA, it can regulate gene transcription, therefore protein synthesis, and ultimately neuronal function (Walters, 1985). Some outcomes of estradiol and/or progesterone treatment are changes in second messenger systems (Etgen and Petitti, 1986), peptide expression (Treiser and Wardlaw, 1992), and neurotransmitter release (Etgen et al., 1992).

With the development of Fos immunocytochemistry, it is now possible to determine the expression of immediate early gene products that suggest neuronal activity (Morgan et al., 1987). Fos, as other immediate early gene products (e.g., jun), is a transcription factor that is expressed rapidly in response to cellular stimulation and may then regulate the expression of other proteins (Sheng and Greenberg, 1990; Curran, 1992). Fos immunocytochemistry has been used to identify neurons which respond to physiologically relevant stimuli such as vaginal-cervical (Tetel et al., 1993) and photic stimulation (Chambille et al., 1993).

Previous studies have shown that treatment with estradiol induces Fos expression in the rat uterus, chick oviduct, and MCF-7 cells in vitro (for review, see Schuchard et al., 1993; Weisz and Bresciani, 1993). Progesterone has been suggested to either decrease Fos expression (Kirkland et al., 1992) or have no effect in the rat uterus (Gibbs et al., 1990). Although estradiol has been shown to induce Fos expression in restricted areas of the female rat brain (Cattaneo and Maggi, 1990; Insel, 1990; Jennes et al., 1992), another report found no induction of Fos by estradiol (Gibbs et al., 1990). However, previous reports are in agreement in showing that subsequent treatment with progesterone is without apparent effect on Fos expression in the rat brain (Gibbs et al., 1990; Insel, 1990).

In order to determine if estradiol and/or progesterone induce Fos expression in female rat brain under conditions similar to those used to induce sexual behavior, we immunocytochemically stained Fos protein after giving behaviorally effective doses of steroid hormones. In addition, we used computer-aided image 
analyses, as this enables the detection of cells with subtle increases in Fos expression. Furthermore, with the aid of image analysis, changes in the intensity of Fos immunoreactivity (FosIR) in individual cells among the treatment groups can be distinguished.

\section{Materials and Methods}

Animals. Female Sprague-Dawley rats (200-250 gm) obtained from Charles River Breeding Laboratories, Inc, (Wilmington, MA) were group housed for 1 week in a 14:10 light:dark cycle. All rats were then ovariectomized under methohexital sodium anesthesia $(52 \mathrm{mg} / \mathrm{kg}$ body weight, Brevital, Eli Lilly and Co., Indianapolis, IN) prior to experiment.

Hormone treatment. One week following surgery, experimental rats were injected with $5 \mu \mathrm{g}$ of estradiol benzoate (dissolved in $0.1 \mathrm{ml}$ of sesame oil) followed by either $500 \mu \mathrm{g}$ of progesterone (dissolved in 0.1 $\mathrm{ml}$ of sesame oil containing $5 \%$ benzyl alcohol and $15 \%$ benzyl benzoate, $n=4)$ or vehicle $(0.1 \mathrm{ml}$ sesame oil, $n=5)$ approximately 48 hr later. In addition, control rats $(n=5)$ were injected with vehicle at both times. One hour after the final injection, the rats were perfused.

Perfusion. Animals were anesthetized with sodium pentobarbital and chloral hydrate. The heart was then exposed and the left ventricle was injected with $5000 \mathrm{U}$ of sodium heparin dissolved in $1 \mathrm{ml}$ of saline $(0.15 \mathrm{M})$. The right atrium and the left ventricle were incised prior to insertion of a cannula, through the incision of the left ventricle, into the aorta. Seventy-five milliliters of saline preceded the flow of $250 \mathrm{ml}$ of fixative ( $2 \%$ acrolein in $0.1 \mathrm{M}$ sodium phosphate buffer; $\mathrm{pH} 7.2$ ) through the cannula. Perfusion pressure was maintained at $100 \mathrm{~mm} \mathrm{Hg}$ with a flow rate of $25 \mathrm{ml} / \mathrm{min}$ for $10 \mathrm{~min}$. After the brains were removed and blocked, they were placed into $0.1 \mathrm{M}$ sodium phosphate buffer ( $\mathrm{pH} 7.2$ ) containing $20 \%$ sucrose overnight at $4^{\circ} \mathrm{C}$. Forty micrometer sections were cut on a freezing microtome from the preoptic area to the midbrain region and placed into cryoprotectant (Watson et al., 1986) at $20^{\circ} \mathrm{C}$ until processed concurrently for immunocytochemical detection of the Fos protein.

Fos immunocytochemistry. For each animal, a set of one in four sections was removed from cryoprotectant and rinsed three times for $5 \mathrm{~min}$ each in Tris-buffered saline (TBS, $\mathrm{pH}$ 7.6). Sections were then pretreated in $1 \%$ sodium borohydride for $10 \mathrm{~min}$ to remove residual aldehydes. Following pretreatment and three additional rinses in TBS for $5 \mathrm{~min}$ each, sections were placed into $1 \% \mathrm{H}_{2} \mathrm{O}_{2}, 20 \%$ normal goat serum, and $1 \%$ bovine serum albumin for $20 \mathrm{~min}$ to reduce nonspecific staining and endogenous peroxidase activity. Sections were then incubated in a polyclonal rabbit $c$-fos antiserum $(0.2 \mu \mathrm{g} / \mathrm{ml}$ in experiment $1 ; 0.1 \mu \mathrm{g} /$ $\mathrm{ml}$ in expcriment 2; Ab-2, Oncogene Science, Inc., lot 3921601, Uniondale, NY) diluted in modified TBS $\left(\mathrm{pH} 7.6,4^{\circ} \mathrm{C}\right)$ containing $0.1 \%$ gelatin, $0.02 \%$ sodium azide, $0.5 \%$ Triton $X-100$, and $1 \%$ normal goat serum for $2 \mathrm{~d}$ at $4^{\circ} \mathrm{C}$. Following three rinses with the above modified TBS buffer ( $\mathrm{pH}$ 7.6) for $5 \mathrm{~min}$ each, the tissue sections were then incubated in a secondary serum $(7.5 \mu \mathrm{g} / \mathrm{ml}$ of biotinylated goat antirabbit IgG; Vector Laboratories, Burlingame, CA) diluted in the modified TBS ( $\mathrm{pH} \mathrm{7.6)}$ for $90 \mathrm{~min}$ at room temperature. Sections were then rinsed twice in the modified TBS (pH 7.6) and once in TBS ( $\mathrm{pH} \mathrm{7.6)}$ for $5 \mathrm{~min}$ each prior to incubation in the DH:biotinylated horseradish peroxidase $\mathrm{H}$ complex [1:100 in TBS (pH 7.6); Vectastain Elite Kit; Vector Laboratories, Burlingame, C.A] for $90 \mathrm{~min}$. Following three additional rinses in TBS $(\mathrm{pH} \mathrm{7.6)}$ of 5 min each, sections were treated with $0.05 \%$ diaminobenzidine and $0.05 \% \mathrm{H}_{2} \mathrm{O}_{2}$ in TBS $(\mathrm{pH} 7.6)$ for 5 min. Immediately after diaminobenzidine treatment, sections were rinsed three times for 5 min each in TBS ( $\mathrm{pH}$ 7.6) and mounted onto glass slides with Permount (Fisher Scientific, Pittsburgh, PA).

Computer-aided image analysis. A Leilz Dialux 20 microscope (Ernst Leitz Wetzler GMBH, Germany) was fitted with a MTI CCD72 camera (DAGE MTI, Michigan City) connected to a Macintosh Quadra 700 (Apple Computer, Cupertino, CA). The software used to determine number and intensity of Fos immunostaining cells was IMAGE 1.47 (W. Rasband, NIH, Bethesda, MD).

Prior to tissue examination, the microscope was adjusted for Kohler illumination using $10 \times 10$ magnification. The minimum and maximum particle size to be analyzed was set to 10 and 60 pixels, respectively. The following analysis proceeded with the experimenter blind to the treatment groups. A random tissue section with Fos-IR was placed under the microscope and viewed on the monitor. The camera gain and black levels were adjusted so that no more than $10 \%$ of Fos-IR cells in the section were at the maximum gray level of 255 . Two additional sections were analyzed to confirm that the gray scale criteria had been met. This allowed the gray level range of Fos-IR within each cell to be from 0 to 255 ( 0 being white, 255 being black). Once the camera gain and black levels were adjusted, they remained calibrated for all sections to be analyzed through a given area. Average background pixel density for each section was determined by averaging the maximum pixel density of five 225 square pixel areas in Fos-IR poor areas of that section. The density threshold option was then adjusted so that the minimum to he analyzed was set to the average hackground pixel density. One carefully matched section per animal through each area was then analyzed bilaterally making adjustments for background variations only, using the above procedure. Fos. IR cell number and maximum pixel density (i.e., optical density) per cell was recorded in each section bilaterally.

Neuroanatomical areas analyzed. Representative sections of areas associated with reproduction that contain steroid receptors, such as the medial amygdala, the medial preoptic area, the ventromedial hypothalamus, and the dorsomedial hypothalamus, were matched as described in the rat brain atlas of Paxinos and Watson (1986; Fig, 1A-C). In addition, the area lateral to the ventromedial hypothalamus described in Figure $1 A$ was examined, as this is a site containing an abundance of progestin (J. D. Blaustein, unpublished observations) and estrogen-receptor immunoreactive cells (Blaustein, 1993).

Statistics. Bilateral measurements of each area were pooled and analyzed using SIGMASTAT Statistical Analysis System 1.01 (Jandel Scientific, Corta Madera, CA). Results from the one-way analyses of variance were considered statistically significant at a probability level of less than 0.05 .

\section{Results}

\section{Experiment 1}

The number of cells expressing Fos-IR in a section of the medial preoptic area and the dorsomedial hypothalamus was higher in both the estradiol alone and estradiol plus progesterone groups when contrasted with vehicle-injected controls $(p<0.05$; Fig. 2). However, there was no difference in Fos-IR cell number between the estradiol alone and estradiol plus progesterone treatment groups $(p>0.05)$. In contrast, there was no increase in Fos-IR after estradiol alone or estradiol plus progesterone treatment in the medial amygdala, the ventromedial hypothalamus, or the area lateral to the ventromedial hypothalamus when compared with controls.

Although the number of Fos-IR cells did not differ between the hormone treated groups, the Fos-IR reaction product appeared to be darker in the progesterone-treated group. Overall, the mean maximum optical density following estradiol alone was not significantly increased by a subsequent injection of progesterone $(p>0.05)$. However, in the medial preoptic area and dorsomedial hypothalamus sections, significantly more cells with a maximum pixel density of 200 or greater were found in the estradiol plus progesterone group than the estradiol alone group ( $p<0.05$; Fig. 3). In contrast, there was no effect of steroid hormone on the intensity of Fos-IR in the medial amygdala section, the ventromedial hypothalamus, or the area lateral to the ventromedial hypothalamus when compared with controls. Thus, although treatment with estradiol followed by progesterone did not increase the number of Fos-IR cells when compared with the estradiol alone group, progesterone treatment did increase the immunostaining intensity (i.e., optical density) of FosIR cells in localized regions of female rat brain.

\section{Experiment 2}

The purpose of experiment two was to determine if lowering the concentration of the Fos antiserum, which would decrease Fos-IR intensity, would provide a means by which to observe a progesterone-induced increase in the number of Fos-IR cells. Using frozen sections from the same animals as experiment one, 
A

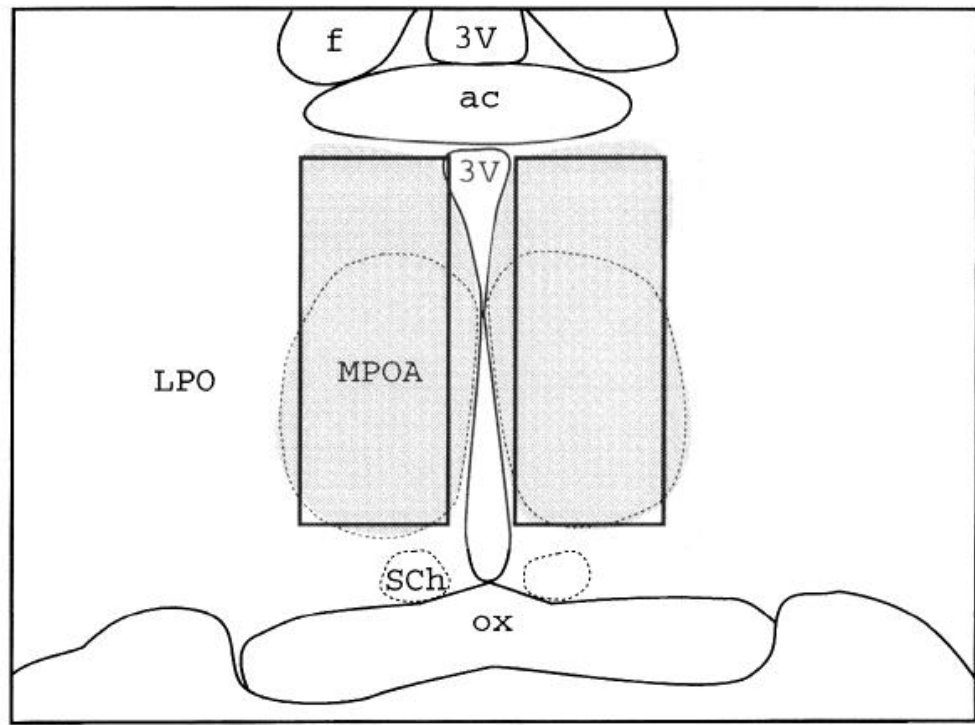

B

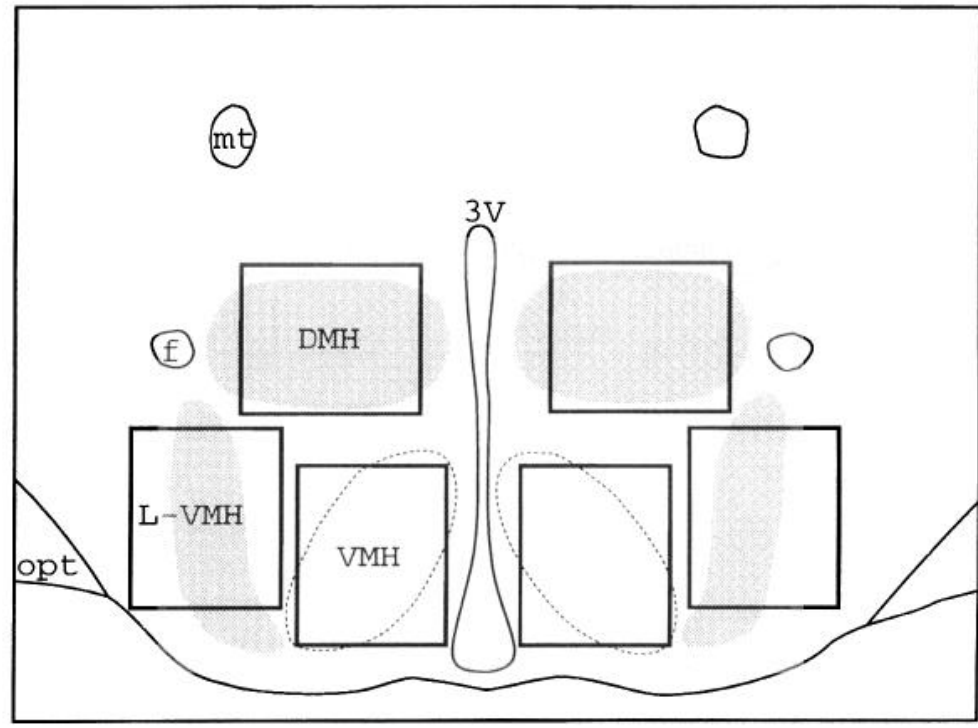

Figure 1. Computer-imaged tracing of areas in which Fos-IR cells were analyzed. Boxes represent the individual areas that were analyzed. Gray areas represent areas of maximum Fos-IR. A: $M P O A$, medial preoptic area including the medial preoptic nucleus; $S C h$, suprachiasmatic nucleus; $L P O$, lateral preoptic area. $B: D M H$, dorsomedial hypothalamus; $V M H$, ventromedial hypothalamus; $L-V M H$, area lateral to the VMH that includes estrogen and progestin receptor containing cells. $C$ : $M e P D$, posterodorsal portion of the medial amygdala; $M e P V$, posteroventral portion of the medial amygdala; $P M C o$, posteromedial cortical amygdaloid nucleus; $I$, intercalated nuclei amygdala; $B M A$, basomedial amygdala; $B L A$, basolateral amygdala. $m t$, mammillothalamic tract; $f$, fornix; $3 V$, third ventricle; opt, optic tract; $a c$, anterior commissure; ox, optic chiasm; st, stria terminalis.

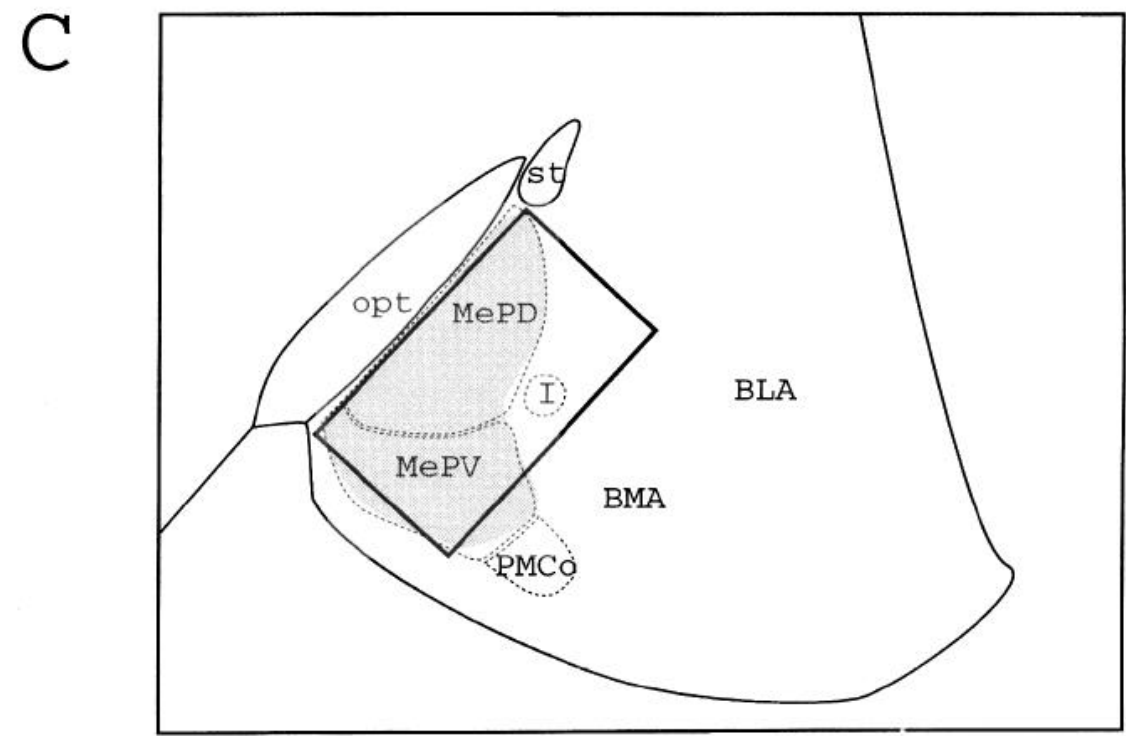




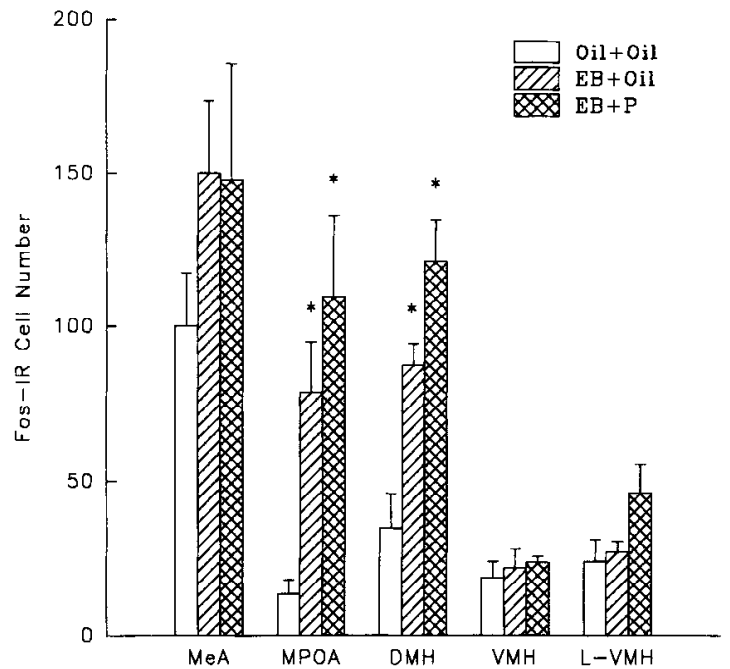

Figure 2. Number (mean \pm SEM) of Fos-IR cells counted bilaterally for each area from vehicle $($ Oil + Oil $)$, estradiol alone $(E B+O i l)$, and estradiol plus progesterone $(E B+P)$ treated animals using $0.2 \mu \mathrm{g} /$ $\mathrm{ml}$ Fos antiserum. *, Significantly different from controls $(p<0.05)$.

a concentration of Fos antiserum was chosen which reduced the number of Fos-IR cells in the estradiol-treated group to a level not significantly different from oil-injected controls in any of the regions exanined. As predicted from the results of experiment one, there remained a substantial increase in Fos-IR cell number within a section of the medial preoptic area, dorsomedial hypothalamus, and the steroid receptor-rich area lateral to the ventromedial hypothalamus of the estradiol plus progesterone treated group compared with the estradiol alone group and vehicle group ( $p<0.05$; Fig. 4). Although there was an increase in FosIR observed in the ventromedial hypothalamus it did not reach statistical significance $(p=0.053)$. Interestingly, under these immunocytochemical conditions, the number of Fos-IR cells in the estradiol plus progesterone treatment group was also significantly greater than the vehicle-treated group in the medial amygdala $(p<0.05)$. However, there was no difference between the two hormone treated groups in the medial amygdala.

\section{Discussion}

Our findings suggest that treatment with behaviorally effective doses of ovarian steroid hormones induces Fos-IR in matched sections of localized regions of female rat brain. In experiment 1 , injection of $5 \mu \mathrm{g}$ of estradiol benzoate increased the number of cells expressing Fos-IR within the medial preoptic area and the dorsomedial hypothalamus sections (Fig. 2). This increase in Fos-IR cell number was unaffected by subsequent treatment with progesterone. However, the number of Fos-IR cells differed between estradiol alone and estradiol plus progesterone treatment when the most darkly immunostained cells (those cells with a maximum pixel density of 200 or greater) were selected. In the medial preoptic area and the dorsomedial hypothalamus sections, the number of darkly immunostained cells following estradiol plus progesterone treatment was significantly higher than the estradiol alone group (Fig. 3). Thus, estradiol treatment increased Fos-IR cell number within the medial preoptic area and the dorsomedial hypothalamus and subsequent injection of progesterone further increased the intensity of Fos-IR within these areas.

In experiment 2 , we lowered the concentration of Fos anti-

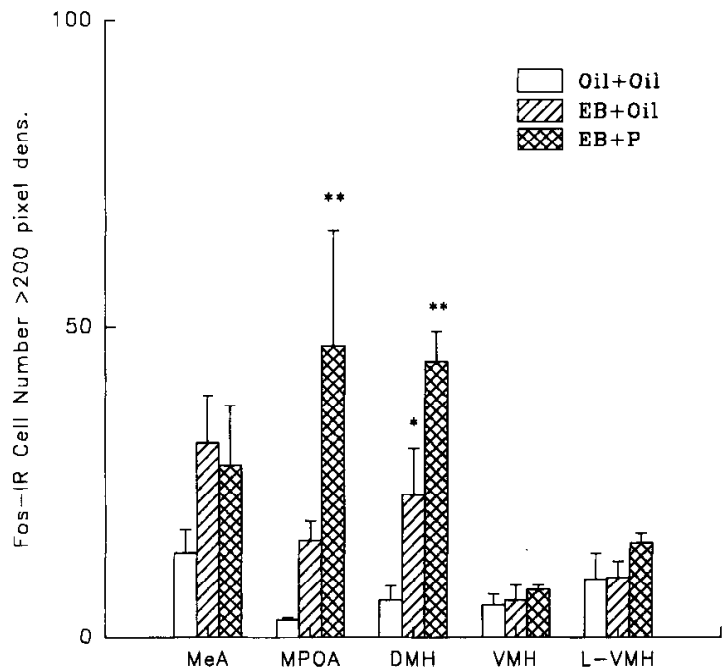

Figure 3. Number (mean \pm SEM) of Fos-IR cells counted bilaterally for each area from the same vehicle $(O i l+O i l)$, estradiol alone $(E B$ $+O i l)$, and estradiol plus progesterone $(E B+P)$ treated animals using $0.2 \mu \mathrm{g} / \mathrm{ml}$ Fos antiserum but only counting those Fos-IR cells with a maximum pixel density of 200 or greater. *, Significantly different from controls $(p<0.05){ }^{* *}$, Significantly different from both groups $(p<$ $0.05)$.

serum in order to diminish Fos-IR to a level in which no increase of Fos-IR cell number was observed after estradiol treatment. As expected, lowering Fos antiserum concentration resulted in a decrease in the total number of cells expressing Fos-IR. Under these immunocytochemical conditions, no statistically significant difference in Fos-IR cell number was observed between the estradiol alone and vehicle treatment groups. However, the number of cells expressing Fos-IR in the estradiol plus progesterone treatment group was elevated in a section of the medial preoptic area, dorsomedial hypothalamus, and the area lateral to the ventromedial hypothalamus when compared to estradiol alone and vehicle treatment groups (Fig. 4). Interestingly, while there was

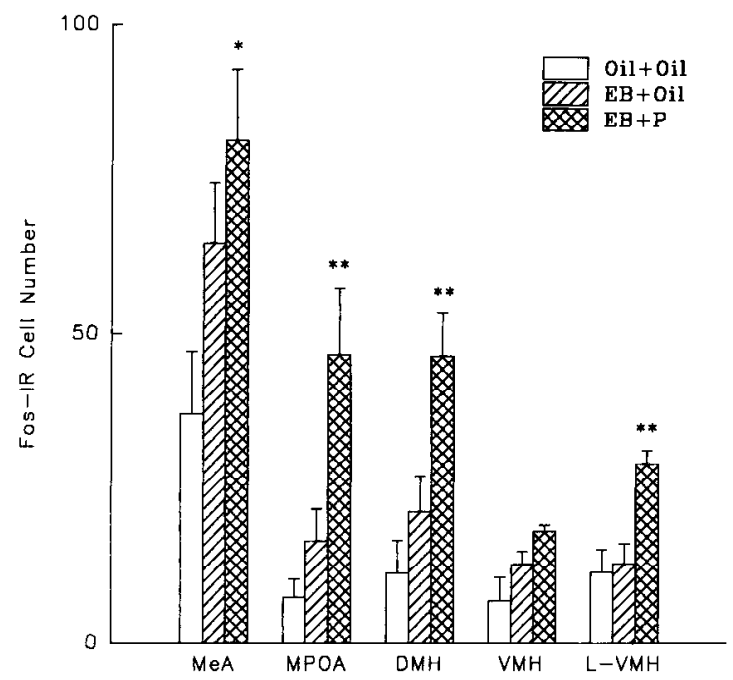

Figure 4. Number (mean \pm SEM) of Fos-IR cells counted bilaterally for each area from vehicle $(O i l+$ Oil $)$, estradiol alone $(E B+O i l)$, and estradiol plus progesterone $(E B+P)$ treated animals using $0.1 \mu \mathrm{g} /$ $\mathrm{ml}$ Fos antiserum. *, Significantly different from controls $(p<0.05)$. **, Significantly different from both groups $(p<0.05)$. 
no difference between the hormone-treated groups in the medial amygdala, treatment with progesterone increased the number of Fos-IR cells when compared with the vehicle treated group. In addition, there was a slight increase in Fos-IR cell number within the ventromedial hypothalamus but it did not reach statistical significance $(p=0.053)$. While lowering Fos antiserum concentration dramatically decreased overall Fos-IR cell number, an increase in Fos-IR cell number was observed with estradiol plus progesterone treatment in localized regions of female rat brain (Fig. 5). Determination of whether changes seen in Fos-IR are specific to the particular rostrocaudal levels analyzed or can be generalized to other levels within each neuroanatomical area will require further analysis.

These findings suggest that changes in the intensity of immunostaining can be correlated with changes in antigen concentration. Several previous studies have shown that increased optical density can be used as a marker for increased antigen concentrations (Rhodes et al., 1981; Benno et al., 1982a,b). Previously, quantitative immunohistochemistry was used to demonstrate reductions in the optical density of oxytocin concentrations in the presence of estradiol and by water deprivation within the anterior commissural nuclei of female rats (Rhodes et al., 1981). In other studies, the optical density of tyrosine hydroxylase, measured by image analysis, was shown to vary with the location of the cell within the locus coeruleus (Benno et al., 1982b) and with treatment by reserpine (Benno et al., 1982a). In addition, it was recently reported that the intensity of Fos expression, which was determined by image analysis, is differentially regulated by different patterns of electrical stimulation (Sheng et al., 1993). Thus, under some conditions image analysis may be a useful technique in semiquantitation of immunocytochemistry to assess relative changes in protein concentration and activity.

Our results are supported by other reports of the effects of steroid hormones on Fos expression in female rats (Cattaneo and Maggi, 1990; Inscl, 1990; Jennes et al., 1992). Inscl (1990) found that injection of a high dose $(100 \mu \mathrm{g} / \mathrm{kg})$ of estradiol benzoate increased Fos-IR in the anterior medial preoptic area, the medial preoptic area, the medial amygdala nucleus, and the ventromedial nucleus of the hypothalamus. This increase in Fos expression occurred between $12-48 \mathrm{hr}$ after estradiol benzoate administration. In addition, Insel (1990) found that injection of a lower dose of estradiol benzoate $(10 \mu \mathrm{g} / \mathrm{kg})$ induced an increase of Fos expression at $48 \mathrm{hr}$ but only in the anterior medial preoptic area. No additional increase in Fos-IR cell number was observed when female rats were given the high dose of estradiol benzoate followed by $(500 \mu \mathrm{g} / \mathrm{kg})$ progesterone $44 \mathrm{hr}$ later and examined at $48 \mathrm{hr}$ (Insel, 1990). Thus, the increase in Fos expression in this study was somewhat dose dependent and seemed not to be altered by a subsequent injection of progesterone. It should be noted that Insel (1990) used a Fos antibody with an epitope in the mid-region of the Fos protein, a site that is homologous among Fos-related antigens (Sheng and Greenberg, 1990; Hoffman et al., 1992). Therefore, even oil-injected controls had numerous Fos-IR cells, a number greatly in excess of that seen in the present experiments in which we used an antibody which recognized the N-terminal of the Fos protein that is specific for the Fos protein (Hoffman et al., 1992).

In another study, Jennes et al., (1992) observed that ovariectomized rats implanted with estrogen-containing SILASTIC (Dow Corning) tubing for 2 weeks showed a moderate (although not statistically significant) $19 \%$ increase in Fos expression with- in the noradrenergic neurons of the $\mathrm{A} 2$ region. However, three hours after a single subcutaneous injection of estradiol $(100 \mu \mathrm{g} /$ $\mathrm{kg}$ ), there was a $79 \%$ increase of Fos expression in the A2 region. In addition, Cattaneo and Maggi (1990) observed an increase in $c$-fos mRNA in the midbrain of ovariectomized rats 30 min after a subcutaneous injection of estradiol $(375 \mu \mathrm{g} / \mathrm{kg})$. These studies provides further evidence that treatment with estradiol increases Fos expression in female rat brain.

In contrast to our data and others (Cattaneo and Maggi, 1990; Insel, 1990; Jennes et al., 1992), there is conflicting evidence that suggests steroid hormones do not induce Fos expression in female rat brain (Gibbs et al., 1990). Gibbs (1990) found no induction of Fos-IR in rats injected concurrently with $5 \mu \mathrm{g}$ of estradiol in ethanol/saline plus $5 \mu \mathrm{g}$ estradiol benzoate in sesame oil and examined 24 hr later. Furthermore, no increase of FosIR was evident in rats that received estradiol followed by $1 \mathrm{mg}$ of progesterone $24 \mathrm{hr}$ later and perfused $4 \mathrm{hr}$ later. It should be noted that Insel (1990) found that the greatest increase in FosIR occurred at $48 \mathrm{hr}$, which is consistent with our findings. Indeed, hormonal stimulation of the proto-oncogene $c$-fos has been shown to induce a peak at $2 \mathrm{hr}$, which declines in 4-8 hr, and induces a second peak of c-fos mRNA $33 \mathrm{hr}$ later in the rat uterus (Weisz and Bresciani, 1988). Together, these studies suggests that treatment with estradiol may induce two waves of Fos expression, an early one within $3 \mathrm{hr}$ (Weisz and Bresciani, 1988; Cattaneo and Maggi, 1990; Jennes et al., 1992) and a second 48 hr later (Insel, 1990).

Although previous reports were consistent in finding that subsequent treatment with progesterone does not alter Fos-IR cell number in female rat brain (Gibbs et al., 1990; Insel, 1990), the time interval following stimulation may account for this difference. In the previous experiments (Gibbs et al., 1990; Insel, 1990) Fos-IR cell number was assessed $4 \mathrm{hr}$ after progesterone injection. In contrast, we examined Fos-IR cell number and intensity $1 \mathrm{hr}$ after injection of progesterone. Indeed, previous reports suggested that Fos may be maximally cxpresscd 60-90 min after stimulation and persist for 2-5 hr (Hoffman et al., 1992, 1993; Weisz and Bresciani, 1993). Thus, it is possible that the previous investigation may have assessed Fos-IR after the peak. Alternatively, our use of an immunocytochemical procedure in which the antiserum concentration was decreased to minimize Fos-IR in the controls may have been more suitable for observing this effect.

It is possible that the neurons exhibiting increased levels of Fos-IR after steroid hormone treatment may be associated with the effects of hormonal conditioning that elicit reproductive behavior. The effect of estradiol and progesterone on Fos-IR could be indirect, such as through transsynaptic connections (Weisz and Bresciani, 1993), or direct as all areas containing Fos-IR also contain estrogen and/or progestin receptors (Rainbow et al., 1982; Blaustein, 1992, 1993). Indeed, estrogen response elements were found in the 5'-flanking sequence (Hyder et al., 1991b) and 3'-flanking sequence (Hyder et al., 1991a) of the mouse $c$-fos oncogene. It is possible that direct receptor-mediated action of estradiol and progesterone on Fos expression could occur within the same neurons, as virtually all cells containing estradiol-induced progestin receptors also contain estrogen receptors (Blaustein and Turcotte, 1989; Warembourg et al., 1989). Alternatively, some of the effects of ovarian steroids on Fos expression could be mediated by membrane receptors for the steroid hormone (Frye and Debold, 1993).

One possible pathway by which estradiol and/or progesterone 


\section{$.2 \mu \mathrm{g}$ Fos Antiserum}

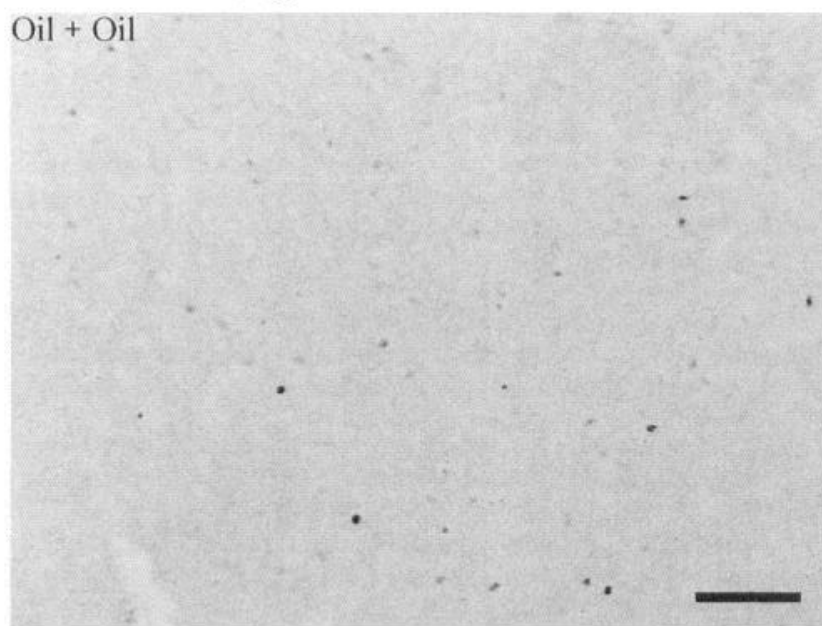

$x$ number of cells $=34$

$x$ number of cells $>200$ pixels $=6$

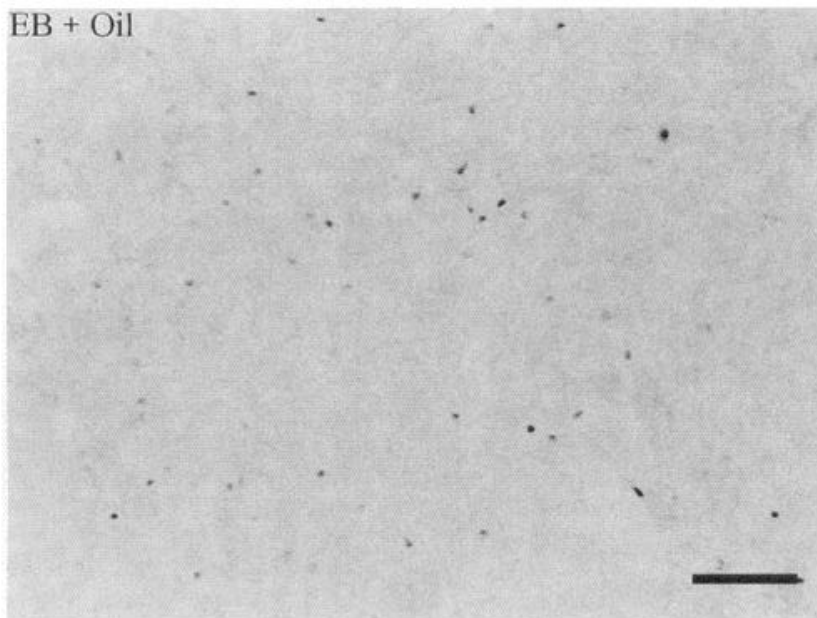

$x$ number of cells $=87$

$x$ number of cells $>200$ pixels $=23$

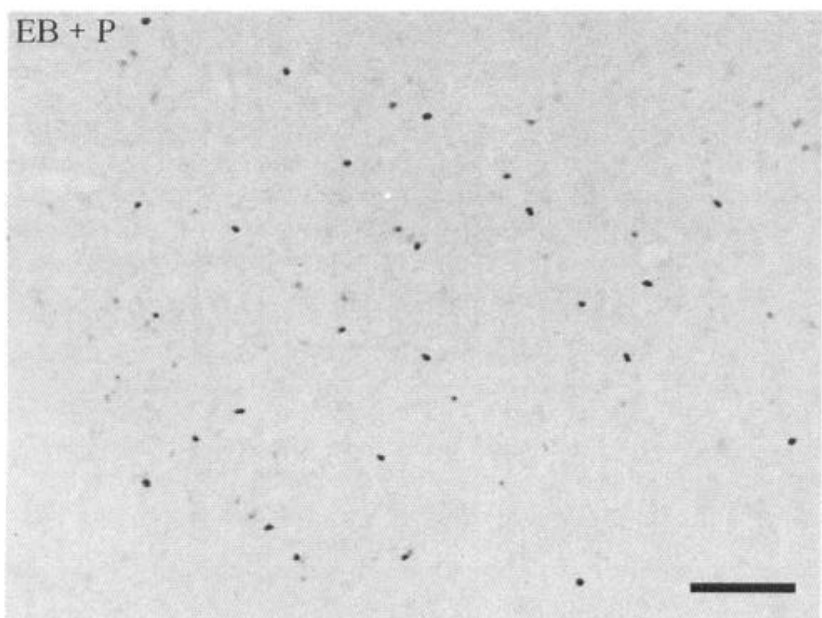

$x$ number of cells $=121$

$x$ number of cells $>200$ pixels $=44$
$.1 \mu \mathrm{g}$ Fos Antiserum

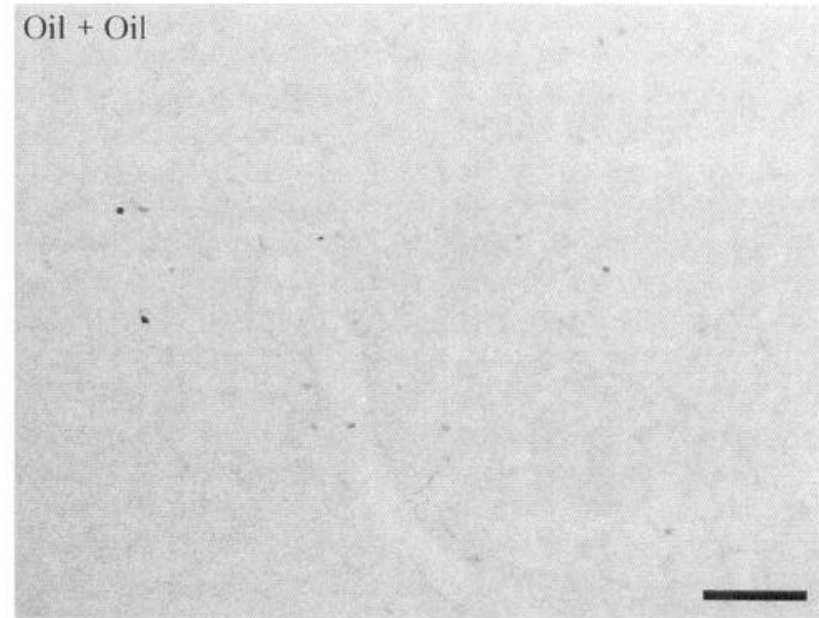

$\mathrm{x}$ number of cells $=11$

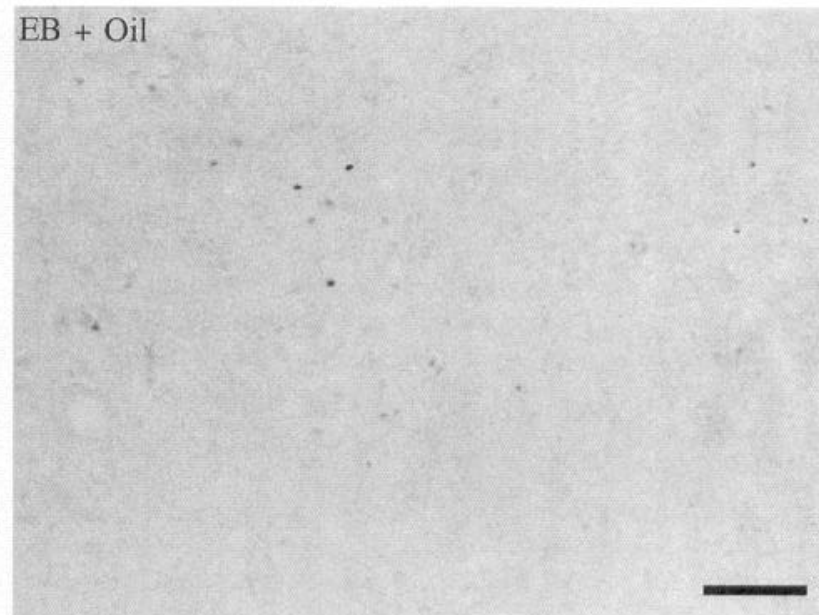

$\overline{\mathrm{x}}$ number of cells $=21$

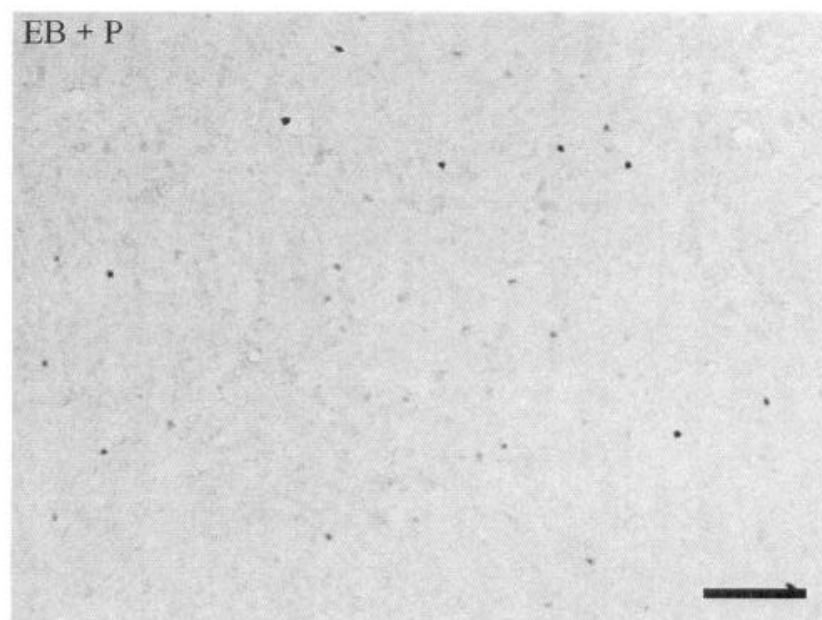

$\mathrm{x}$ number of cells $=46$

Figure 5. Photomicrograph of Fos-IR in the DMH from vehicle $(O i l+O i l)$, estradiol alone $(E B+O i l)$, and estradiol plus progesterone $(E B+$ $P$ ) treated animals using $0.2 \mu \mathrm{g} / \mathrm{ml}$ Fos antiserum (left column, experiment one) and $0.1 \mu \mathrm{g} / \mathrm{ml}$ Fos antiserum (right column, experiment 2). Mean number of cells represents the mean number of Fos-IR cells counted bilaterally for that group. Mean number of cells $>200$ pixels represents the mean number of Fos-IR cells expressing 200 or greater maximum pixel density for that group. Scale bar, $100 \mu \mathrm{m}$. 
could regulate Fos-IR indirectly is by modulating catecholamine transmission. Previously, it has been reported that treatment with estradiol and progesterone induce Fos-IR within gonadotropinreleasing hormone $(\mathrm{GnRH})$ containing neurons at the time of the LH surge (Hoffman et al., 1990, 1992; Lee et al., 1990; Wu et al., 1992). GnRH activity is influenced by the noradrenergic system (Kalra and Kalra, 1984). Indeed, noradrenergic neurons project onto GnRH containing neurons (Jennes et al., 1982; Wright and Jennes, 1993) and to the areas in which we find Fos-IR induced by steroid hormones (Ricardo and Koh, 1978). The primary source of noradrenergic projections to $\mathrm{GnRH}$ cells comes from the A1 and A2 cell groups (Wright and Jennes, 1993) which express increased Fos-IR following estradiol treatment (Jennes et al., 1992). In addition, noradrenergic transmission in the hypothalamus, which is increased by steroid hormone treatment (Vathy and Etgen, 1988; Etgen et al., 1992), has been shown to induce Fos expression in rat brain (Bing et al., 1991, $1992 \mathrm{a}, \mathrm{b})$. The noradrenergic system is important in modulating GnRH activity (Kalra and Kalra, 1984), steroid receptors (Blaustein et al., 1986; Blaustein, 1987; Blaustein and Letcher, 1987), and reproductive behaviors (Etgen, 1990).

In summary, our findings suggest that treatment with behaviorally effective doses of ovarian steroid hormones induce Fos expression in localized regions of female rat brain. Estradiol and progesterone may induce Fos-IR directly by binding to a steroid response element on the $c$-fos gene (Weisz and Bresciani, 1988, 1993; Hyder et al., 1991a,b; Schuchard et al., 1993), indirectly, for example through the noradrenergic system (Bing et al., 1991, $1992 \mathrm{a}, \mathrm{b})$, or both. The steroid-hormone induced Fos protein may then regulate the expression of other gene products (Sheng and Greenberg, 1990; Curran, 1992) that are involved in reproductive behaviors.

\section{References}

Benno RH, Tucker LW, Joh TH, Reis DJ (1982a) Quantitative immunocytochemistry of tyrosine hydroxylase in rat brain. I. Development of a computer assisted method using the peroxidase-antiperoxidase technique. Brain Res 246:225-236.

Benno RH, Tucker LW, Joh TH, Reis DJ (1982b) Quantitative immunocytochemistry of tyrosine hydroxylase in rat brain. II. Variations in the amount of tyrosine hydroxylase among individual neurons of the locus coeruleus in relationship to neuronal morphology and topography. Brain Res 246:237-247.

Bing G, Filer D, Miller JC, Stone EA (1991) Noradrenergic activation of immediate early genes in rat cerebral cortex. Mol Brain Res 11: 43-46.

Bing G, Chen S, Zhang Y, Hillman D, Stone EA (1992a) Noradrenergic-induced expression of c-fos in rat cortex: neuronal localization. Neurosci Lett 140:260-264.

Bing G, Stone EA, Zhang Y, Filer D (1992b) Immunohistochemical studies of noradrenergic-induced expression of $\mathrm{c}$-fos in the rat CNS. Brain Res 592:57-62.

Blaustein ID (1987) The alpha-1-noradrenergic antagonist prazosin decreases the concentration of estrogen receptors in female rat hypothalamus. Brain Res 404:39-50.

Blaustein JD (1992) Cytoplasmic estrogen receptors in rat brain: im munocytochemical evidence using three antibodies with distinct epitopes. Endocrinology 131:1336-1342.

Blaustein JD (1993) Estrogen receptor immunoreaclivity in rat brain rapid effects of estrodiol injection. Endocrinology 132:1218-1224.

Blaustein JD, Letcher B (1987) Noradrenergic regulation of cytosol estrogen receptors in female rat hypothalamus: possible role of alpha2-noradrenergic receptors. Brain Res 404:51-57.

Blaustein JD, Turcotte JC (1989) Estradiol-induced progestin receptor immunoreactivity is found only in estrogen receptor-immunoreactive cells in guinea pig brain. Neuroendocrinology 49:454-461.

Blaustein JD, Brown TJ, Swearengen ES (1986) Dopamine-beta-hydroxylase inhibitors modulate the concentration of functional estro- gen receptors in female rat hypothalamus and pituitary gland. Neuroendocrinology 43:150-158.

Boling JL, Blandau RJ (1939) The estrogen-progesterone induction of mating responses in the spayed female rat. Endocrinology 25:359364.

Cattaneo E, Maggi A (1990) c-fos induction by estrogen in specific rat brain areas. Eur J Pharmacol 188:153-159.

Chambille I, Doyle S, Serviere J (1993) Photic induction and circadian expression of fos-like protein-immunohistochemical study in the retina and suprachiasmatic nuclei of hamster. Brain Res 612:138-150.

Curran T (1992) Fos and jun-oncogenic transcription factors. Tohoku J Exp Med 168:169-174.

Etgen AM (1990) Intrahypothalamic implants of noradrenergic antagonists disrupt lordosis behavior in female rats. Physiol Behav 48:3136.

Etgen AM, Petitti N (1986) Norepinephrine-stimulated cAMP accumulation in rat hypothalamus slices: effects of estrous cycle and ovarian steroids. Brain Res 375:385-390.

Etgen AM, Ungar S, Petitti N (1992) Estradiol and progesterone modulation of norepinephrine neurotransmission: implications for the regulation of female reproductive behavior. J Neuroendocrinol 4:255271

Frye CA, Debold JF (1993) P-3-BSA, but not p-11-BSA, implants in the VTA rapidly facilitate receptivity in hamsters after progesterone priming to the VMH. Behav Brain Res 53:167-175.

Gibbs RB, Mobbs CV, Pfaff DW (1990) Sex steroids and Fos expression in rat brain and uterus. Mol Cell Neurosci 1:29-40.

Hoffman GE, Lee WS, Attardi B, Yann V, Fitzsimmons MD (1990) Luteinizing hormone neurons express $\mathrm{c}$-fos antigen after steroid aclivation. Endocrinology 126:1736-1741.

Hoffman GE, Smith MS, Fitzsimmons MD (1992) Detecting steroidal effects on immediate early gene expression in the hypothalamus. Neuroprotocols 1:52-66.

Hoffman GE, Smith MS, Verbalis JG (1993) c-fos and related immediate early gene products as markers of activity in neuroendocrine systems. Front Neuroendocrinol 14:173-213.

Hyder SM, Cram LF, Loose-Mitchell DS (1991a) Sequence of a 1.4$\mathrm{kb}$ region in the 3 '-flanking region of the murine $\mathrm{c}$-fos proto-oncogene which contains an estrogen-response element. Gene 105:281282.

IIyder SM, Stancel GM, Loose-Mitchell DS (1991b) Presence of an estradiol response region in the mouse c-fos oncogene. Steroids 56: -504 .

Insel TR (1990) Regional induction of c-fos-like protein in rat brain after estradiol administration. Endocrinology 126:1849-1853.

Jennes L, Beckman WC, Stumpf WE, Grzanna R (1982) Anatomical relationships of serotoninergic and noradrenalinergic projections with the GnRH system in septum and hypothalamus. Exp Brain Res 46: 331-338.

Jennes L, Jennes ME, Purvis C, Nees M (1992) c-fos expression in noradrenergic A2 neurons of the rat during the estrous cycle and after steroid hormone treatments. Brain Res 586:171-175.

Jensen EV, Suzuki T, Kawashima T, Stumpf WE, Jungblut PW, DeSombre ER (1968) A two-step mechanism for the interaction of estradiol with rat uterus. Proc Natl Acad Sci USA 59:632-638.

Kalra SP, Kalra PS (1984) Opioid-adrenergic-steroid connection in regulation of luteinizing hormone secretion in the rat. Neuroendocrinology $38: 418-426$.

Kirkland JL, Murthy L, Stancel GM (1992) Progesterone inhibits the estrogen-induced expression of c-fos messenger ribonucleic acid in the uterus. Endocrinology 130:3223-3230.

Lee WS, Smith MS, Hoffman GE (1990) Progesterone enhances the surge of luteinizing hormone by increasing the activation of luteinizing hormone-releasing hormone neurons. Endocrinology 127:2604 2606.

Morgan JI, Cohen GR, IIempstead JL, Curran T (1987) Mapping patterns of c-fos expression in the central nervous system after seizure. Science 237:192-196.

Paxinos G, Watson C (1986) The rat brain in stereotaxic coordinates. Sydney: Academic.

Powers JB (1970) Hormonal control of sexual receptivity during the estrous cycle of the rat. Physiol Behav 5:831-835.

Rainbow TC, Parsons B, MacLusky NJ, McEwen BS (1982) Estradiol receptor levels in rat hypothalamic and limbic nuclei. J Neurosci 2:1439-1445. 
Rhodes CH, Morrell JI, Pfaff DW (1981) Changes in oxytocin content in the magnocellular neurons of the rat hypothalamus following water deprivation or estrogen treatment. Cell Tissue Res 216:47-55.

Ricardo JA, Koh ET (1978) Anatomical evidence of direct projections from the nucleus of the solitary tract to the hypothalamus, amygdala, and other forebrain structures in the rat. Brain Res 153:1-26.

Schuchard M, Landers JP, Sandhu NP, Spelsberg TC (1993) Steroid hormone regulation of nuclear proto-oncogenes. Endocr Rev 14:659 669.

Sheng HZ, Fields RD, Nelson PG (1993) Specific regulation of immediate early genes by patterned neuronal activity. J Neurosci Res 35:459-467.

Sheng M, Greenberg ME (1990) The regulation and function of c-fos and other immediate early genes. Neuron 4:477-485.

Smith MS, Freeman ME, Neill JD (1975) The control of progesterone secretion during the estrous cycle and early pseudopregnancy in the rat: prolactin, gonadotropin and steroid levels associated with rescue of the corpus luteum of pseudopregnancy. Endocrinology 96:219 226

Tetel MJ, Getzinger MJ, Blaustein JD (1993) Fos expression in the rat brain following vaginal-cervical stimulation by mating and probing. J Neuroendocrinol 5:397-404.

Treiser SL, Wardlaw SL (1992) Estradiol regulation of proopiomelan- ocortin gene expression and peptide content in the hypothalamus. Neuroendocrinology 55:167-173.

Vathy I, Etgen AM (1988) Ovarian steroids and hypothalamic norepinephrine release: studies using in vivo brain microdialysis. Life Sci 43:1493-1499.

Walters MR (1985) Steroid hormone receptors and the nucleus. Endocr Rev 6:512-543.

Warembourg M, Jolivet A, Milgrom E (1989) Immunohistochemical evidence of the presence of estrogen and progesterone receptors in the same neurons of the guinea pig hypothalamus and preoptic area. Brain Res 480:1-15.

Watson RE, Wiegand SJ, Clough RW, Hoffman GE (1986) Use of cryoprotectant to maintain long-term peptide immunoreactivity and tissue morphology. Peptides 7:155-159.

Weisz A, Bresciani $F$ (1988) Estrogen induces expression of $c$-fos and c-myc protononogenes in rat uterus. Mol Endocrinol 2:816-824.

Weisz A, Bresciani F (1993) Estrogen regulation of proto-oncogenes coding for nuclear proteins. Crit Rev Oncogen 4:361-388.

Wright DE, Jennes L (1993) Origin of noradrenergic projections to gnRH perikarya-containing areas in the medial septum-diagonal band and preoptic area. Brain Res 621:272-278.

Wu TJ, Segal AZ, Miller GM, Gibson MJ, Silverman AJ (1992) Fos expression in gonadotropin-releasing hormone neurons: enhancement by steroid treatment and mating. Endocrinology 131:2045-2050. 